\title{
RESISTANCE PROFILE OF MULTIDRUG-RESISTANT URINARY TRACT INFECTIONS AND THEIR SUSCEPTIBILITY TO CARBAPENEMS
}

\author{
CARMEN MANCIUC ${ }^{1,2}$, IOANA FLORINA MIHAI ${ }^{1 *}$, FLORINA FILIP-CIUBOTARU $^{2}$, \\ GEORGIANA ALEXANDRA LACATUSU ${ }^{1}$
}

1 "Sf Parascheva” Infectious Diseases Clinical Hospital Iași, Romania

2 "Grigore T. Popa" University of Medicine and Pharmacy Iași, Romania

*corresponding author: iordanioana06@gmail.com

\begin{abstract}
Improper use of antibiotics has led, over time, to different resistance profiles of bacteria in association with a decrease in antibiotic efficacy. The long term of non- judicious administration of antibiotic lead to the emergence of multidrug-resistant (MDR) strains. The existence of MDR to the most utilized groups of antibiotics has become a serious public health concern. In the context of the emergence of MDR urinary tract infections (UTIs), this paper aims to determine the bacteria resistance spectrum, as well as their sensitivity to carbapenems. For this, our retrospective study observed the urine cultures of the patients admitted in "Sf Parascheva" Clinical Hospital of Infectious Diseases in Iași, Romania, for signs and/or symptoms for a UTI in the first 6 months of 2019. We took into account only patients that were admitted to our hospital and had microbiological confirmed UTI. From all the urine cultures analysed in the studied period, 70 MDR strains were isolated, from which, 25 extended-spectrum beta-lactamases (ESBL) producing bacteria with Escherichia coli being the predominant bacteria (38.6\%). Regarding the susceptibility to antibiotics, the highest sensitivity of the tested strains was recorded for carbapenems. Improper diagnosis and irrational antibiotic therapy for UTIs accelerated the emergence of resistant multidrug strains. Treatment should be done according to the antibiogram, for a sufficiently long period to avoid resistance. The resistance to all antibiotics, even those that are considered the last line of treatment, represents the highest risk that the future imposes.
\end{abstract}

\section{Rezumat}

Utilizarea necorespunzătoare a antibioticelor a dus, de-a lungul timpului, la diferite profiluri de rezistență ale bacteriilor, în asociere cu o scădere a eficacității antibioticelor. Perioada îndelungată în care nu a existat o administrare judicioasă a antibioticelor a dus la apariția tulpinilor multidrug rezistente (MDR). Existența MDR la cele mai utilizate grupuri de antibiotice a devenit o problemă serioasă de sănătate publică. În contextul apariției infecțiilor urinare (ITU) cu bacterii MDR, această lucrare își propune să determine spectrul de rezistență al acestora, precum și sensibilitatea la carbapeneme. Pentru aceasta am analizat retrospectiv uroculturile pacienților care s-au prezentat cu semne și simptome de ITU, ce au fost tratați în primele 6 luni ale anului 2019 la Spitalul Clinic de Boli infecțioase Sf Parascheva din Iași, Romania. Dintre toate uroculturile analizate în perioada studiată, au fost izolate 70 de tulpini MDR, dintre care, 25 producătoare de beta-lactamaze cu spectru extins, predominând Escherichia coli $(38,6 \%)$. În ceea ce privește susceptibilitatea la antibiotice, cea mai mare sensibilitate a tulpinilor testate a fost la carbapeneme. Diagnosticarea necorespunzătoare şi antibioterapia irațională a ITU accelerează apariția tulpinilor multidrog rezistente. Tratamentul trebuie făcut conform antibiogramei, pe o perioadă suficient de lungă pentru a evita apariția rezistenței. Rezistența la toate antibioticele, chiar și la cele considerate ultima linie de tratament, reprezintă cel mai mare risc pe care îl impune viitorul.

Keywords: urinary tract infection, multidrug-resistance, carbapenems

\section{Introduction}

Urinary tract infections (UTIs) are among the most commonly reported diseases, occupying the fourth position of all healthcare-associated infections, representing the most common infection that needs an antibiotic prescription [22]. According to the official guidelines and recommendations published by the US Center for Disease Control and Prevention (CDC), multidrug-resistant organisms (MDRs) are predominantly bacteria, which are resistant to one or more antimicrobial agents from different classes [13, 14].
The constant worldwide growing resistance of bacteria to antimicrobial drugs gives all medical practitioner a great concern, so it is important to limit the use of antibiotics only to situations that require. Limiting broad-spectrum empiric treatment to particular cases (for example patients with risk factors etc.) and, besides, perform a correct treatment according to antibiogram, may contribute to slowing the continuously increase of the bacteria resistance $[1,5,6,19,20]$.

Carbapenems, represented by meropenem, ertapenem, doripenem, imipenem/cilastatin, have one of the broadest 
spectrums of activity over bacteria. This group of antibiotics should be used as a last resort for the treatment of severe or high-risk bacterial infections. Because of their potency, these antibiotics are considered "backup" for those infections that are caused by MDR strains $[3,8,10]$. Like the other classes of antimicrobial beta-lactams, carbapenems manifest their activity by inhibiting bacterial cell wall synthesis [18].

The spectrum of activity of carbapenems includes most gram-negative and gram-positive, aerobic and anaerobic bacteria, cocci and bacilli [19]. Sensitive organisms include Bacteroides spp., Haemophilus influenzae, Neisseria gonorrhoeae, Neisseria meningitidis, Salmonella and Shigella spp., Staphylococcus aureus, Streptococcus pneumoniae, Listeria monocytogenes. Few bacteria, like Pseudomonas cepacia, Enterococcus faecium and some other Enterococcus species are naturally resistant to these antimicrobials. Methicillinresistant strains of $S$. aureus and coagulase-negative staphylococci have different susceptibility to carbapenems $[13,18,21]$.

Carbapenems represent the primary choice in the treatment of severe infections for extended-spectrum beta-lactamases (ESBLs) producing bacteria [3, 22]. Clinical data to compare the effectiveness of various compounds (imipenem/cilastatin, meropenem, ertapenem and, more recently, doripenem) are still limited [1, 4]. Regarding the current study, our concern focused on highlighting the susceptibility spectrum of urinary tract infections with multidrug-resistant bacteria to carbapenems and, at the same time, the resistance profile of these infections. Also, we took into consideration that the MDRs are resistant to at least 5 different antibiotics.

\section{Materials and Methods}

Study design and patients selection

We conducted an observational retrospective study using the hospital-based medical records of patients with a diagnosis of UTI hospitalized in the Infectious Diseases Clinical Hospital in Iași, Romania, during January - June 2019. In the study, we included inpatients with microbiologically confirmed UTI defined by the growth of MDR bacteria $\geq 10^{5}$ colony forming units $(\mathrm{CFU}) / \mathrm{L}$.

Extrapolating the definition of the term MDR mentioned above, we included in our study only the urine cultures of the patients that showed bacteria that were resistant to more than five antibiotics, regardless of the class of origin, thus, obtaining 46 positive samples with multi-resistant germs. We collected information about: demographic data regarding the age, sex, area of residence (urban or rural), the presence of comorbidities or relapses of the current disease, the causes of urinary tract infections, laboratory data (urinalysis, urine culture), the presence of multidrugresistant strains and the performed treatment. The antibiogram performed after the urine cultures of the samples were interpreted according to the European Committee on Antimicrobial Susceptibility Testing (EUCAST) guidelines [9, 10, 17]. Two-tailed paired t-test was used to obtain statistical significance.

Isolation and identification of uropathogenic strains The sample of urine was obtained by the clean-catch method or by briefly inserting a sterile catheter through the urethra into the bladder. The most commonly used criterion for defining significant bacteriuria is the presence of $\geq 10^{5} \mathrm{CFU} / \mathrm{mL}$. The complete urinalysis involved three steps: 1 . assessment of the colour, cloudiness and concentration of the urine; 2 . examination of the chemical composition of the urine using a test strip and 3. examination of the urine under a microscope to look for bacteria, cells and parts of cells. After seeding, incubation, was done at $35-37^{\circ} \mathrm{C}$ for 18 - 24 hours.

The obtained results were semi-quantitative and expressed as the number of CFU/mL [9]. The urine sample was cultured on agar plates for growth, concentration, identification and isolation. Urine cultures containing bacteria exceeding the threshold of $10^{5} \mathrm{CFU} / \mathrm{mL}$ are considered positive, whether we are talking about one or more isolated bacteria [18]. Antibiotic susceptibility testing

For the complete diagnosis, the AST (antimicrobial susceptibility testing) was performed. AST is typically conducted as a phenotypic assay that measures bacterial growth in the presence of specific antimicrobial agents. AST takes an additional 24 - 48 hours and leads to results for each pathogen-antimicrobial combination. It is interpreted according to EUCAST guidelines and reported as sensitive, intermediate, or resistant [10, 11, 13, 15]. The modified Kirby-Bauer disc diffusion method [7, 10, 11] was used and the test antibiotics were ampicillin (AMP), amoxicillin/clavulanic acid (AUG), amikacin (AMK), nitrofurantoin (NTR), tobramycin (TBR), colistin (COL), carbapenems (CR), cotrimoxazole (CTX), fluoroquinolones (FLQ), cephalosporins II+III (CEF) and piperacillin/tazobactam (PIP-TAZO). Also, the multiple antibiotic resistance (MAR) index of each antibiotic was calculated.

Management of UTI

There were only two cases of uncomplicated urinary tract infection caused by E. coli. The average length of hospitalization was 9 days. Cases of uncomplicated urinary tract infection received treatment with antibiotics based on the $3^{\text {rd }}$ generation of cephalosporins, and in complicated cases treatment with nitrofurantoin (30.4\% of cases), carbapeneme ( $45.6 \%$ of cases) and colistin ( $10.8 \%$ of cases) was used. Complete remission of UTI was noted for all treatments.

\section{Results and Discussion}

During the above-mentioned period, a total number of 782 patients were hospitalized in our clinic for 
suspicion of urinary tract infection (patients presented signs and symptoms of a UTI). From those, in 359 cases the urine cultures tested positive, out of which 46 with MDR germs (70 strains).

Regarding the demographic characteristics of the patients, the mean age was 63 years, with age that varied from 12 to 93 years old. The majority of cases were encountered in female gender $(60.8 \%)$ and in patients that came from the urban environment (65.2\%). Clinical characteristics of patients were summarized in Table I. The majority of the patients had multiple comorbidities $(91.3 \%)$ as indicated in Table II. There were also cases identified at patients in the intensive care unit (32.6\%).

Table I

Clinical characteristics of patients

\begin{tabular}{|l|c|c|}
\hline \multirow{2}{*}{ CHARACTERISTICS } & \multicolumn{2}{c|}{ PATIENTS WITH MDR BACTERIURIA } \\
\cline { 2 - 3 } & $\mathrm{n}=46$ & \multicolumn{2}{c|}{63} \\
\hline Age (years) & \multicolumn{2}{|c|}{$12-93$} \\
Median range & $28: 18$ & $60.8: 39.2$ \\
\hline Female:male ratio & $30: 16$ & $65.2: 34.8$ \\
\hline Urban:rural ratio & 15 & 32.6 \\
\hline History of UTI & 43 & 93.4 \\
\hline Underlying disease & 40 & 86.9 \\
\hline Dysuria & 46 & 100 \\
\hline Abdominal pain & 36 & 78.2 \\
\hline Fever & 44 & 95.6 \\
\hline Urgency & 15 & 32.6 \\
\hline Intensive care unit & 5 & 10.8 \\
\hline Antibiotic prophylaxis & & \\
\hline
\end{tabular}

Table II

Risk factors frequency in the investigated patients with UTI

\begin{tabular}{|l|c|}
\hline \multicolumn{1}{|c|}{ RISK FACTORS/ COMORBIDITIES } & FREQUENCY (\%) \\
\hline Urinary catheter & 43.5 \\
\hline Hypertension & 28.2 \\
\hline Diabetes & 15.2 \\
\hline Acute kidney failure & 17.4 \\
\hline Chronic kidney disease & 13 \\
\hline
\end{tabular}

As compared to other studies, the main risk factor for our patients was catheterization, followed by hypertension and kidney failure [7, 10, 13, 15, 22]. Analysing the data found in the hospital-based medical records in which we found a complete anamnesis performed at the moment of admittance in the hospital we concluded that $15(32.6 \%)$ patients had relapses of the disease, 41 (89.1\%) patients were hospitalized for a different pathology and $38(82.6 \%)$ came by transfer from other clinics (Figure

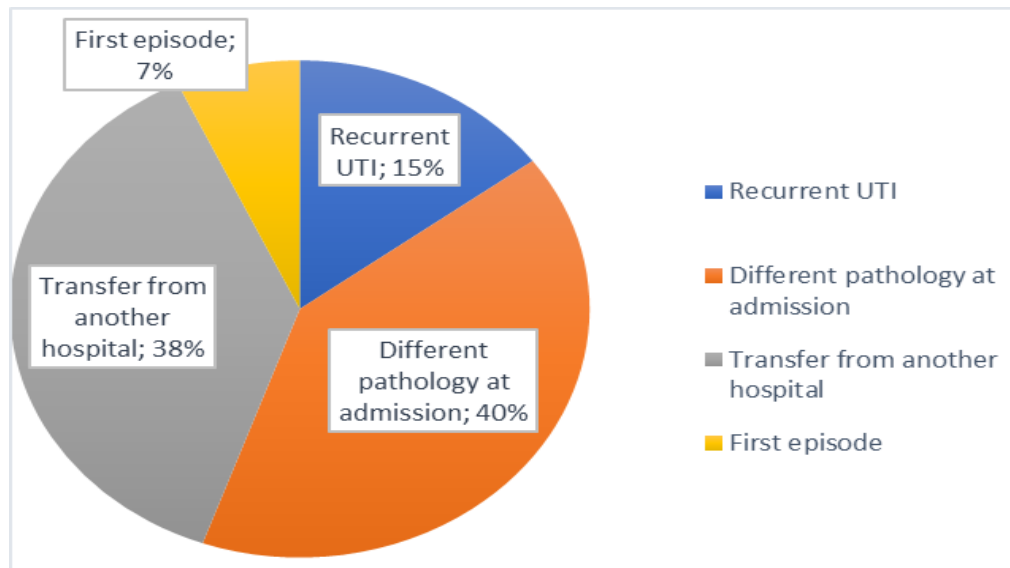

Figure 1.

The prevalence of different types of UTI admitted in the clinic

Following the laboratory data, we quantified the spectrum and frequency of the strains detected in the urine samples of the patients included in the study group diagnosed with UTI (Table III). 
FARMACIA, 2020, Vol. 68, 4

\section{Table III}

The spectrum of urinary tract infections in the study

group

\begin{tabular}{|l|c|c|}
\hline \multicolumn{1}{|c|}{ Microorganism } & No of cases & Percentage \\
\hline Escherichia coli & 27 & 38.6 \\
\hline Klebsiella spp. & 10 & 14.3 \\
\hline Klebsiella pneumoniae & 9 & 12.8 \\
\hline Enterococcus spp. & 7 & 10 \\
\hline Candida spp. & 7 & 10 \\
\hline Enterococcus faecalis & 4 & 5.7 \\
\hline Proteus mirabilis & 3 & 4.2 \\
\hline Pseudomonas aeruginosa & 3 & 4.2 \\
\hline
\end{tabular}

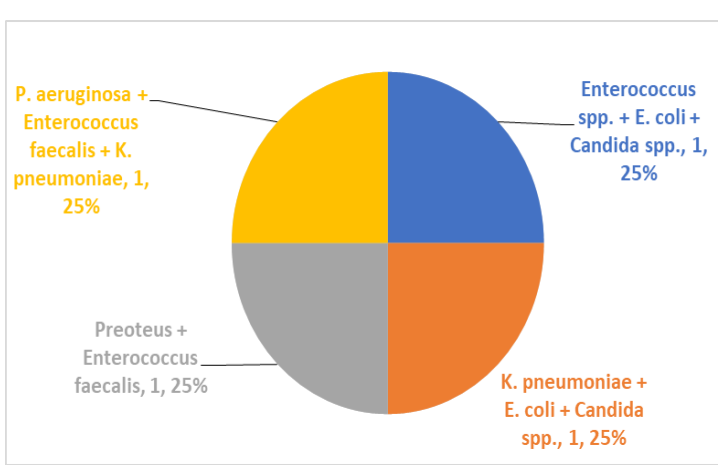

Figure 2.

Types of isolated colonies with 4 different strains

From 46 urine samples included in our study, in 4 samples three types of colonies were isolated (Figure 2), whereas, in the other 16 samples two types of bacteria were found (Figure 3). A total of 70 MDR strains were isolated.

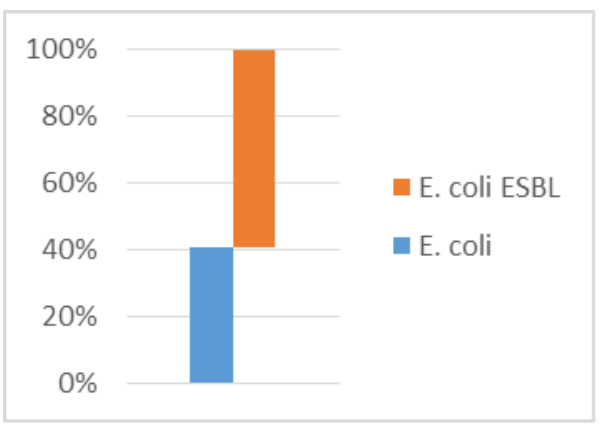

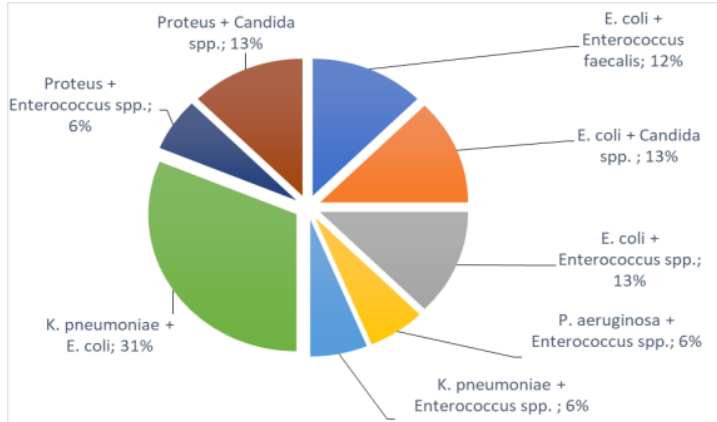

Figure 3.

Types of isolated colonies with 3 different strains

After the data analysis, we concluded that the majority of urinary tract infections had Escherichia coli as a primary pathogen, followed closely by Klebsiella spp. The statistical parameters indicated a significant variation and a direct correlation between the number of cases and the pathogenic strains $(\mathrm{r}=0.9999 ; \mathrm{p}<0.05)$. Out of the 27 Escherichia coli isolates, 16 strains were producing extended-spectrum beta-lactamases (ESBLs). There were only two cases of uncomplicated urinary tract infection caused by E. coli. Moreover, from the 19 Klebsiella spp isolates, 9 were also ESBL (Figure 4). However, lower frequencies were noted for Enterococcus spp., Proteus mirabilis and Pseudomonas aeruginosa strains.

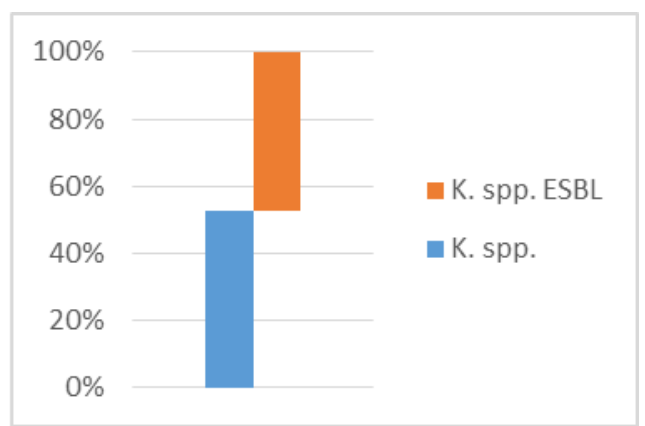

Figure 4.

Viscosity curves and the statistical mean of differences expressed by the regression lines

In vitro testing showed different degrees of resistance to various classes of antibiotics, which underlines the importance of performing the antibiogram for correct and complete therapy of these infections.
Table IV includes the results obtained for the resistance test for the most frequent pathogens detected in the investigated urine cultures.

Table IV

Antibiotic resistance table for E. coli and Klebsiella spp.

\begin{tabular}{|c|c|c|c|c|c|c|c|c|c|c|c|}
\hline \multirow{2}{*}{ Pathogen } & \multicolumn{8}{|c|}{ No. of isolates resistant to antibiotics/Total cases } \\
\cline { 2 - 13 } & AMP & FLQ & CEF & CTX & TBR & NTR & AUG & AMK & CR & COL \\
\hline \multirow{2}{*}{ E. coli } & cases/total & $27 / 27$ & $24 / 27$ & $25 / 27$ & $17 / 27$ & $5 / 27$ & $3 / 27$ & $15 / 27$ & $5 / 27$ & $0 / 27$ & $0 / 27$ \\
\cline { 2 - 12 } & $\%$ & 100 & 88.89 & 92.59 & 62.96 & 18.52 & 11.11 & 55.55 & 18.52 & 0 & 0 \\
\hline \multirow{2}{*}{ Klebsiella spp. } & cases/total & $12 / 19$ & $19 / 19$ & $9 / 19$ & $0 / 19$ & $8 / 19$ & $12 / 19$ & $19 / 19$ & $9 / 19$ & $5 / 19$ & $0 / 19$ \\
\hline & $\%$ & 63.16 & 100 & 47.36 & 0 & 42.11 & 63.16 & 100 & 47.36 & 26.32 & 0 \\
\hline
\end{tabular}




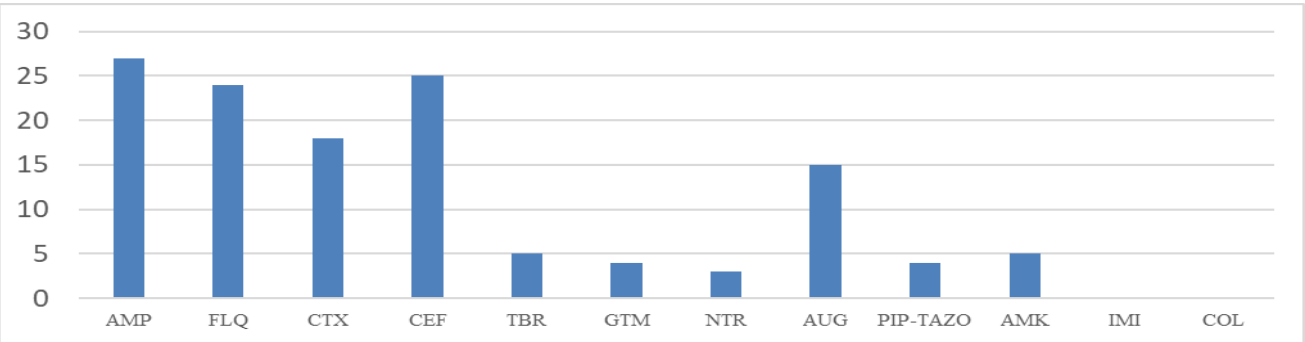

Figure 5.

Antimicrobial resistance of Escherichia coli (no. of cases)

AMP (ampicillin), FLQ (fluoroquinolones), CTX (cotrimoxazole), CEF (cephalosporins II+III), TBR (tobramycin), GTM (gentamycin), NTR (nitrofurantoin), AUG (amoxicillin/clavulanic acid), PIP-TAZO (piperacillin/tazobactam), amikacin (AMK), COL (colistin), CR (carbapenems, either imipenem or meropenem)

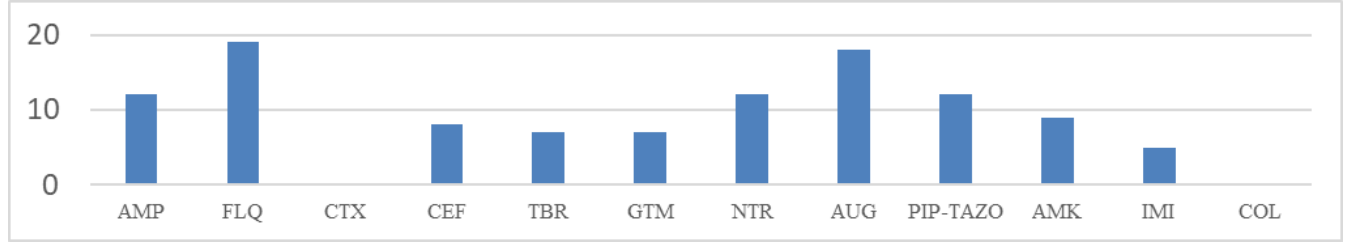

Figure 6.

Antimicrobial resistance profile of Klebsiella spp. (no. of cases)

AMP (ampicillin), FLQ (fluoroquinolones), CTX (cotrimoxazole), CEF (cephalosporins II+III), TBR (tobramycin), GTM (gentamycin), NTR (nitrofurantoin), AUG (amoxicillin/clavulanic acid), PIP-TAZO (piperacillin/tazobactam), amikacin (AMK), COL (colistin), CR (carbapenems, either imipenem or meropenem)

Also, Figures 5 and 6 illustrate the degree of resistance (expressed as number of cases) to different classes of antibiotics tested for Escherichia coli and Klebsiella spp. isolated from urine samples.
Regarding the IMAR scores (Figure 7), the highest was found for FLQ (0.93), followed by AMP (0.84) indicating that these antibiotics were highly ineffective against the tested uropathogens.

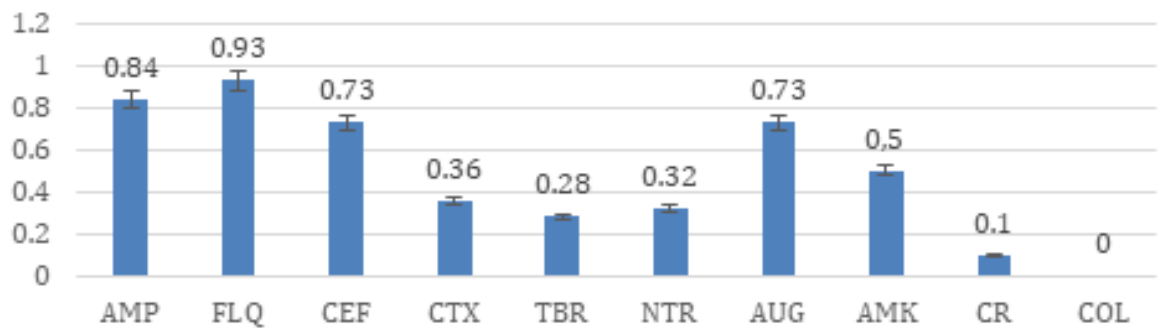

Figure 7.

Overall resistance of all isolated E. coli and Klebsiella spp. uropathogens against tested antibiotics

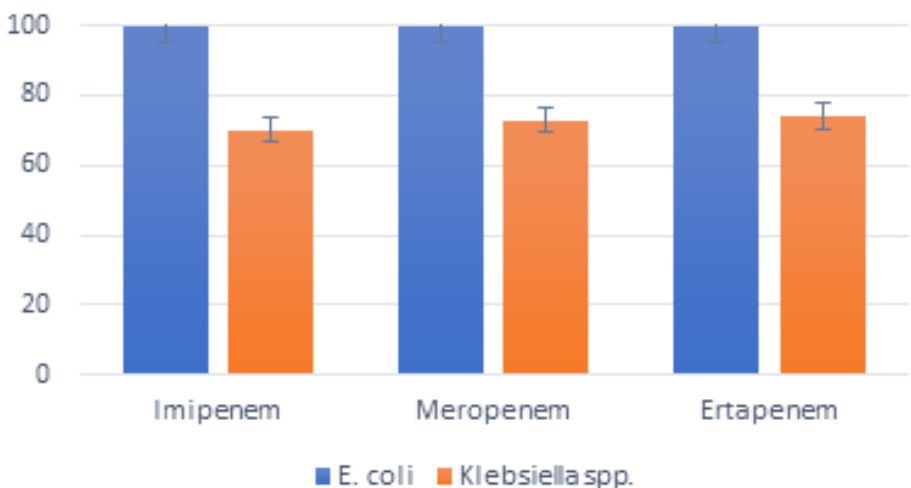

Figure 8.

Percentage susceptibility to carbapenems 
As the results show, we can see that the highest level of resistance for E. coli was obtained in the case of ampicillin. An alarming result was that $E$. coli and Klebsiella spp. had increased resistance to fluoroquinolones. In vitro, the strains isolated from E. coli maintained their sensitivity to colistin and imipenem, and in the case of Klebsiella spp., the only sensitivity was observed for colistin. Moreover, from the total of the 19 tested Klebsiella spp. strains, only five were carbapenem-resistant. The overview of the susceptibility to carbapenems (imipenem, meropenem and ertapenem) of the Escherichia and Klebsiella strains are indicated in Figure 8.

Various risk factors can increase the susceptibility of acquiring MDR bacteria that can cause UTI. As the results showed, elderly population, female gender, urinary catheterization, and multiple hospitalizations are the most encountered risk factors for the observed cases. Also, as the data suggested, associated diseases such as diabetes and other diseases that impair the immune system can increase the risk of UTIs. Such results are confirmed also by the known literature $[1-3,13]$. Moreover, our results are in agreement with the community studies from other countries (India, Italy and UK) in which the most important and frequent bacterial strains identified in clinical isolates were Escherichia coli and Klebsiella sp [5-7, 15, 21]. There are also slight differences in terms of the comorbidities (hypertension and acute kidney failure versus diabetes mellitus and recent urinary infections) that influence the occurrence of UTI in our patients [7]. Most probably, variations are influenced by the lifestyle and ethnical specificity.

However, it is known that previous use of antibiotics may influence the appearance of a urinary tract infection. All over the world, both in the hospital and in the outpatient setting, it is common the concurrent use of multiple drugs and auto medication $[5,6,12]$. Such practices lead to long term risks, usually translated to higher microbial resistance $[5,6,13,14]$.

Noteworthy is the fact that similar to other studies, most of the investigated clinical isolates were resistant to fluoroquinolones while remaining susceptible to carbapenems [21].

The patients with multiple recurrences had experienced depression linked to the gravity of the disease directly proportional to the severity of the illness. In some cases, the intervention of the hospital psychologist was required. The role of this medical intervention is to minimize the burden of this disease $[15,16]$. Knowing the number of the patients that came from different health-care centres or those that acquired a UTI over the time of hospitalization for other diseases we can speculate that the majority of UTI with multidrug-resistant germs were acquired either as a healthcare-associated infection or generated by the resistance of the bacteria that occurred after the multiple courses of antibiotic.
According to European Centre for Disease Prevention and Control, the susceptibility to carbapenems of different bacterial strains is constantly increasing, $K$. pneumoniae, percentages of carbapenem resistance ranging from $0 \%$ to more than $60 \%$, data that are also sustained by the presented study in which $26.31 \%$ of Klebsiella spp. were carbapenem-resistant [15-18]. For this reason, practitioners should opt for limiting their use only in complicated urinary tract infections [18]. Thus, there are concerns about the increased rate of resistance to carbapenems, in the context where there are few therapeutic options for treating infections caused by carbapenem-resistant bacteria (such as Klebsiella pneumoniae and other carbapenem-resistant Enterobacteriaceae).

Limiting the use of invasive devices is another potentially important intervention for limiting the extension of carbapenem-resistant bacteria. Such strains have been identified from device-associated infections, particularly catheter-associated urinary tract infections $[10,11]$.

The results of the study, in conjunction with the literature data, draw attention to the increased antibiotic resistance of microorganisms involved in the aetiology of urinary tract infections, thus exhausting the treatment opportunities. To avoid therapeutic failure and minimize the spread of antibiotic-resistant bacteria, data regarding the natural and acquired resistance of uropathogenic organisms should be known.

\section{Conclusions}

According to the study, Escherichia coli dominated the etiological spectrum of urinary infections, followed further away by Enterococcus sp., Klebsiella spp., Pseudomonas aeruginosa, Proteus mirabilis. All strains of Enterobacteriaceae isolated showed varying levels of antibiotic resistance tested, except for colistin, while in vitro sensitivity was maintained. Overall, the susceptibility to carbapenems was high, preserving their value as a backup antibiotic in the therapy of these infections.

An increasing number of community infections with enterobacteria producing ESBL have been reported in the last two decades. In these cases, carbapenems were used. As such, resistant strains have emerged and thus a major public health problem occurred. To identify the correct treatment, to avoid therapeutic failure and to decrease the spread of antibioticresistant bacterial strains in communities, the urinary tract therapy needs to be based on information. The most reliable information is provided by the epidemiological surveillance and the resistance patterns of uropathogenic bacteria. The obtained results support the importance of monitoring the antibiotic resistance and equipping the bacteriology laboratories with modern means that allow the etiological diagnosis and the early 
establishment of targeted therapy, on a scientific basis, of these infections.

\section{Conflict of interest}

The authors declare no conflict of interest.

\section{References}

1. Anand NI, Parmar DM, Sukhlecha A, Comparison of combinations of ciprofloxacin-metronidazole and ceftriaxone-metronidazole in controlling operative site infections in obstetrics and gynaecological surgeries: A retrospective study. J Pharmacol Pharmacother., 2011; 2(3): 170-173.

2. Dorneanu R, Cioancă O, Chifiriuc O, Albu E, Tuchiluş C, Mircea C, Salamon I, Hăncianu M. Synergic benefits of Aronia melanocarpa anthocyanin-rich extracts and antibiotics used for urinary tract infections. Farmacia, 2017; 65(5): 778-783.

3. Dorobăț C, Dorobăț Gh, Manciuc C, Vâță A, About beta-lactamases....until when?. Med Surg J - Rev Med Chir., 2011; 115(3): 647-655, (available in Romanian).

4. Dorobăț CM, Dorobăț G, Bejan C, Ghibu L, Rosu F, Petrovici C, Loghin I, Manciuc C, Antibiotic therapy in severe sepsis in HIV-positive patients. Med Surg J - Rev Med Chir., 2012; 116(3): 714-717.

5. Durante-Mangoni E, Andini R, Zampino R, Management of carbapenem-resistant Enterobacteriaceae infections. Clinic Microbiol Infect., 2019; 25(8): 943-950.

6. Eshetie S, Unakal C, Gelaw A, Ayelign B, Endris M, Moges F, Multidrug-resistant and carbapenemaseproducing Enterobacteriaceae among patients with urinary tract infection at referral Hospital, Northwest Ethiopia. Antimicrob Resist Infect Control, 2015; 17(4): 1-8.

7. Eshwarappa M, Dosegowda R, Aprameya IV, Khan MW, Kumar PS, Clinico-microbiological profile of urinary tract infection in South India. Indian J Nephrol. 2011; 21(1): 30-36.

8. European Centre for Disease Prevention and Control, Carbapenem-resistant Enterobacteriaceae, second update - 26 September 2019. ECDC: Stockholm; 2019.

9. Filip-Ciubotaru F, Manciuc C, Stoleriu G, Foia L, NADPH oxidase: structure and activation mechanisms (Review). Note I. Med Surg J - Rev Med Chir., 2016; 120(120): 29-33.

10. Gould CV, Umscheid CA, Agarwal RK, Kuntz G, Pegues DA, Guideline for prevention of catheterassociated urinary tract infections. Infect Control Hospital Epidemiol., 2010; 31: 319-326.

11. Golli AL, Nițu FM, Bălășoiu M, Rascu S, Lungu MA, Dinescu SN, Ciobanu-Mitrache L, Glodeanu A, Văcaru M, Olteanu M, Microbiological profile and antibiotic resistance pattern of bacterial uropathogens among hospitalized patients. Farmacia, 2019; 67(1): 167-173.

12. Gupta K, Hooton MH, Naber KG, Wullt B, Colgan R, Miller LG, International clinical practice guidelines for the treatment of acute uncomplicated cystitis and pyelonephritis in women a 2010 update by the infectious diseases society of America and the European society for microbiology and infectious diseases. Clin Infect Dis., 2011; 52(5): e103-e120.

13. Hertz FB, Schønning K, Rasmussen SC, Littauer P, Knudsen JD, Løbner-Olesen A, Frimodt-Møller N, Epidemiological factors associated with ESBL- and non ESBL-producing E. coli causing urinary tract infection in general practice. Infect Dis (Lond)., 2016; 48(3): 241-245.

14. Harrison PF, Lederberg J (eds.), Antimicrobial resistance: Issues and options. National Academy Press, Washington, DC, 1998.

15. Khawcharoenporn $\mathrm{T}$, Vasoo $\mathrm{S}$, Singh K, Urinary Tract Infections due to Multidrug-Resistant Enterobacteriaceae: Prevalence and Risk Factors in a Chicago Emergency Department. Emerg Med Int., 2013; 2013: 1-7.

16. Manciuc C, Largu AM. Impact And Risk Of Institutionalized Environments On The psychoemotional development of the HIV-positive youth. Environ Engin Manag J., 2014; 13(12): 3123-3129.

17. Mihai IF, Lacatusu AG, Filip-Ciubotaru F, Dorobat $\mathrm{C}$, Romanescu C, Manciuc C, Major trends in the microbial etiology of urinary tract infection. Global Advanced Res J Microbiol, 2019; 8(2): 35-37.

18. Petca RC, Popescu RI, Mareș C, Petca A, Mehedințu C, Sandu I, Măru N, Antibiotic resistance profile of common uropathogens implicated in urinary tract infections in Romania. Farmacia, 2019; 67(6): 994-1004.

19. Shaikh S, Fatima J, Shakil S, Rizvi SMD, Kamal MA, Antibiotic resistance and extended-spectrum beta-lactamases types, epidemiology and treatment. Saudi J Biol Sci., 2015; 22(1): 90-101.

20. Tenney J, Hudson N, Alnifaidy H, Li J, Fung KH, Risk factors for acquiring multidrug-resistant organisms in urinary tract infections: A systematic literature review. Saudi Pharmaceut., 2018; 26(5): 678-684.

21. Toner L, Papa N, Aliyu SH, Dev H, Lawrentschuk $\mathrm{N}$, Al-Hayek S, Extended-spectrum beta-lactamaseproducing Enterobacteriaceae in hospital urinary tract infections: incidence and antibiotic susceptibility profile over 9 years. World J Urol., 2016; 34(7): 1031-1037.

22. Vâță A, Hunea IM, Dorneanu O, Harja-Alexa IA, Pleşca C, Leonte-Enache G, Ciocan A, Ghiciuc CM, Esanu I, Manolache M, Luca CM, Biochemical changes and risk factors in the prognosis of antibiotics susceptibility in urinary tract infections. Revista de Chimie, 2019; 70(5):1822-1825. 